\title{
Pengaruh Motivasi dan Model Pembelajaran Advance Organizer Terhadap Hasil Belajar Siswa dalam Pembelajaran IPA
}

\author{
Sofyan S. Bengke ${ }^{1 *}$, Ferdy Dungus ${ }^{2}$ \\ 1,2Jurusan Pendidikan IPA, FMIPA, Universitas Negeri Manado \\ *e-mail: fbengke@gmail.com
}

\begin{abstract}
Abstrak. Penelitian ini dilakukan untuk membahas pengaruh motivasi dan model pembelajaran advance organizer terhadap hasil belajar siswa pada pembelajaran IPA di kelas VII SMP Negeri 2 Tahuna. Uji hipotesis yang digunakan dalam penelitian adalah uji ANAVA dua arah dengan bantuan software SPSS. Uji hipotesis penelitian menunjukan nilai signifikasi untuk metode pembelajaran terhadap hasil belajar siswa sebesar 0,000. Hasil uji hipotesis kedua menunjukan nilai interaksi sebesar 0,000. Hasil uji hipotesis ketiga menunjukan nilai signifikasi untuk model pembelajaran advance organizer pada kelompok motivasi tinggi dengan model pembelajaran konvensional motivasi tinggi sebesar 0,000. Hasil uji hipotesis keempat menunjukan nilai signifikasi untuk untuk model pembelajaran advance organizer pada kelompok motivasi rendah dengan model pembelajaran konvensional motivasi rendah sebesar 0,068. Disimpulkan bahwa Terdapat pengaruh metode pembelajaran terhadap hasil belajar siswa, Terdapat interaksi antara model pembelajaran dan motivasi terhadap hasil belajar, Terdapat pengaruh model pembelajaran advance organizer pada kelompok motivasi tinggi dan metode konvensional pada kelompok motivasi tinggi terhadap hasil belajar siswa, Terdapat pengaruh model pembelajaran advance organizer pada kelompok motivasi rendah dan metode konvensional pada kelompok motivasi rendah terhadap hasil belajar siswa.
\end{abstract}

Kata kunci: advance organizer, motivasi siswa, hasil belajar

\begin{abstract}
This research was conducted to discuss the effect of motivation and advance organizer learning models on student learning outcomes in science learning in class VII SMP Negeri 2 Tahuna. Hypothesis test used in this research is two-way ANAVA test with the help of SPSS software. The research hypothesis test shows the significance value for the learning method towards student learning outcomes of 0.000. The result of the second hypothesis test shows the interaction value of 0,000. The results of the third hypothesis test show the significance value for the advance organizer learning model in the high motivation group with the high motivation conventional learning model of 0.000. The results of the fourth hypothesis test show the significance value for the advance organizer learning model in the low motivation group with the low motivation conventional learning model of 0.068. It is concluded that there is an effect of learning methods on student learning outcomes, there is an interaction between learning models and motivation on learning outcomes, there is an influence of advanced organizer learning models in high motivation groups and conventional methods in high motivation groups on student learning outcomes, there is an influence of advanced organizer learning models in the low motivation group and conventional methods in the low motivation group on student learning outcomes.
\end{abstract}

Keywords: advance organizer, student motivation, learning outcomes 


\section{PENDAHULUAN}

Berhasil tidaknya program pendidikan yang di laksanakan melalui proses belajar mengajar disekolah sebagai lembaga pendidikan formal dapat diamati dari dua sisi, yaitu dari tingkat pemahaman dan penguasaan materi yang diberikan oleh guru. Usaha perencanaan pengajaran di upayakan agar peserta didik memiliki kemampuan maksimum dan meningkatkan motivasi, tantangan dan kepuasan sehingga mampu memenuhi harapan baik oleh guru sebagai pembawah materi maupun peserta didik sebagai penggarap ilmu pengetahuan (Sudjana, 2005).

IPA merupakan salah satu pembelajaran yang menuntut untuk berinteraksi langsung dengan sumber belajar, tidak hanya memahami konsep ilmu pengetahuan saja, namun perlu penggabungan pengalaman melalui serangkaian kegiatan ilmiah sebagai langkah menuju pemahaman terhadap konsep pelajaran IPA. Berpikir metakognitif memastikan bahwa siswa akan mampu menyusun informasi. Hal ini akan tercapai, bila siswa mampu berpikir tentang proses berpikir yang dimilikinya, mengidentifikasi strategi belajar yang baik dan secara sadar mengarahkan belajarnya (Sugiyarto, 2008)

Berdasarkan hasil observasi dan wawancara dengan guru mata pelajaran IPA di SMP Negeri 2 tahuna diperoleh dua permasalahan, pertama adalah penggunaan metode ceramah yang terus menerus dalam setiap mata pelajaran, membuat siswa jenuh dan memilih untuk asyik berbincang-bincang dengan teman sebelah atau bermain-main dan membuat kegaduhan. Hal ini membuat siswa kurang dapat menerima apa yang telah di sampaikan oleh guru, terlihat bila guru memberikan pertanyaan yang bertujuan untuk memancing kosentrasi siswa, siswa tidak dapat menjawab pertanyaan tersebut. Permasalahan yang kedua yang di temukan adalah motivasi belajar siswa yang rendah. Motivasi belajar siswa yang masih rendah terlihat sekali pada saat guru memberikan kesempatan kepada siswa untuk bertanya, tidak seorang pun yang mengacuhkan jari untuk bertanya, begitu pula sebaliknya. Apabila guru memberikan pertanyaan, tidak ada siswa yang berani menjawab pertanyaan tersebut.

Model pembelajaran sebagai suatu acuan kepada suatu pendekatan pemebelajaran termasuk tujuan, sintaksnya, lingkungan dan sistem pengelolaanya. Model pembelajaran yang baik menarik motivasi siswa yang akhirnya terlibat aktif dalam mengikuti dan melaksanakan pembelajaran dengan sebaik-baiknya sehingga dapat mencapai hasil belajar yang di inginkan. Salah satu model pembelajaran yang dapat digunakan yaitu model pembelajaran advance organizer (Slavin, 2010).

Ausubel melihat kegunaan advance organizer sebagai sarana untuk membantu membuat informasi bermakna bagi siswa. Bagi Ausubel, sebuah advance organizer terdiri atas pernyataanpernyataan yang dibuat guru tepat sebelum presentasi aktual berbagai materi belajar. Pernyataan itu memiliki tingkat abstraksi yang lebih tinggi dibanding informasi yang menyusulnya. advance organizer membantu siswa untuk menggunakan pengetahuan sebelumnya (Hartono, 2014)

\section{METODE PENELITIAN}

Penelitian ini dilaksanakan di kelas VII A dan VII B SMPN2 Tahuna, pada semester ganjil tahun ajaran 2017/2018. Dari 23 siswa di kelas eksperimen dibentuk kembali 2 kelompok berdasarkan tingkat motivasi belajar siswa. Pembagian ini dilakukan dengan menggunakan angket motivasi belajar siswa yang diberikan sebelum penerapan metode pembelajaran di kedua kelas dilakukan.

Berdasarkan hasil yang diperoleh dari pemberian angket motivasi belajar diketahui 10 siswa kelas eksperimen masuk dalam kategori siswa dengan motivasi tinggi, 10 siswa masuk dalam kategori siswa dengan motivasi rendah dan 3 siswa masuk dalam kategori siswa dengan motivasi sedang. Dengan cara yang sama dilakukan pembagian kepada 23 siswa di kelas kontrol berdasarkan 
tingkat motivasi belajarnya. Diperoleh hasil 10 siswa masuk kategori siswa dengan motivasi tinggi, 10 siswa masuk kategori siswa dengan motivasi rendah dan 3 siswa masuk dalam kategori siswa motivasi sedang.

Metode penelitian yang digunakan dalam penelitian ini adalah metode eksperimen semu dengan desain penelitian menggunakan desain posttestonly control group design yang disebut juga desain kelompok kontrol dengan tes akhir saja (Sugyono, 2013)

Instrumen yang digunakan dalam penelitian ini meliputi instrumen pembelajaran dan instrumen pengambilan data. Instrumen pembelajaran meliputi Silabus, Rencana Pelaksanaan Pembelajaran (RPP), Lembar Kerja Siswa (LKS). Sedangkan instrumen pengambilan data meliputi instrument angket untuk mengetahui tingkat motivasi siswa dan tes untuk mendapatkan hasil belajar siswa yang berupa soal objektif.

Teknik yang digunakan untuk analisis data pada penelitian dibagi menjadi 2 tahap, yaitu tahap awal dengan melakukan uji normalitas data dengan Shapiro-Wilk (uji W) dan uji homogenitas serta tahap akhir dengan menggunakan uji hipotesis (uji Anava dua arah) dengan bantuan software SPSS 21.

\section{HASIL DAN PEMBAHASAN Hasil Penelitian}

Berdasarkan hasil yang diperoleh dari pemberian angket motivasi belajar diketahui 10 siswa kelas eksperimen masuk dalam kategori siswa dengan motivasi tinggi, 10 siswa masuk dalam kategori siswa dengan motivasi rendah dan 3 siswa masuk dalam kategori siswa dengan motivasi sedang. Dengan cara yang sama dilakukan pembagian kepada 23 siswa di kelas kontrol berdasarkan tingkat motivasi belajarnya. Diperoleh hasil 10 siswa masuk kategori siswa dengan motivasi tinggi, 10 siswa masuk kategori siswa dengan motivasi rendah dan 3 siswa masuk dalam kategori siswa motivasi sedang.

Kelompok siswa ini kemudian diberikan perbedaan perlakukan berupa metode pembelajaran yang digunakan didalam kelas. Kelas eksperimen belajar dengan model pembelajaran advance organizer sedangkan kelas kontrol belajar dengan metode konvensional. Setelah itu kedua kelas diberikan tes akhir.

Data yang diambil adalah data dari hasil belajar siswa yang diperoleh dari posttest dapat dilihat pada Tabel 1.

Tabel 1. Data hasil tes akhir kelas eksperimen dan kelas kontrol

\begin{tabular}{|c|c|c|c|}
\hline \multirow{2}{*}{ B } & \multicolumn{2}{|c|}{$\mathrm{A}$} & \\
\hline & A1 & $\mathrm{A} 2$ & \\
\hline \multirow{12}{*}{ B1 } & 75 & 50 & \multirow{12}{*}{$\begin{array}{l}\bar{x} .77 .25 \\
\text { Sd. } 8.5\end{array}$} \\
\hline & 75 & 50 & \\
\hline & 80 & 55 & \\
\hline & 85 & 60 & \\
\hline & 85 & 60 & \\
\hline & 85 & 65 & \\
\hline & 85 & 65 & \\
\hline & 80 & 65 & \\
\hline & 90 & 70 & \\
\hline & 95 & 75 & \\
\hline & $\bar{x}=83.5$ & $\bar{x}=61.5$ & \\
\hline & $\mathrm{Sd}=6.25$ & $\mathrm{Sd}=8.18$ & \\
\hline \multirow{12}{*}{$\mathrm{B} 2$} & 65 & 55 & \multirow{12}{*}{$\begin{array}{l}\bar{x} .62 .5 \\
\text { Sd. } 8,5\end{array}$} \\
\hline & 65 & 55 & \\
\hline & 65 & 60 & \\
\hline & 70 & 65 & \\
\hline & 70 & 60 & \\
\hline & 70 & 65 & \\
\hline & 75 & 65 & \\
\hline & 75 & 65 & \\
\hline & 75 & 70 & \\
\hline & 80 & 75 & \\
\hline & $\bar{x}=71.0$ & $\bar{x}=63.5$ & \\
\hline & $\mathrm{Sd}=5.16$ & $\mathrm{Sd}=6.25$ & \\
\hline $\bar{x}$ & 72.5 & 67.25 & $\bar{x}=69.88$ \\
\hline $\mathrm{Sd}$ & 13.32 & 6.78 & $\mathrm{Sd}=10.77$ \\
\hline
\end{tabular}

Keterangan:

$\mathrm{A}=$ Model pembelajaran

$\mathrm{B}=$ Motivasi

$\mathrm{A} 1=$ Advance organizer

A2 = Konvensional

$\mathrm{B} 1=$ Motivasi tinggi

$\mathrm{B} 2$ = Motivasi rendah

Berdasarkan uji normalitas data yang dilakukan dengan menggunakan Uji Shapiro-Wilk, diperoleh nilai siswa motivasi tinggi dan rendah di kelas eksperimen dan control memiliki sebaran data normal atau berdistribusi normal. Serta, berdasarkan uji homogenitas data yang dilakukan dengan menggunakan Uji 
Levene, uji homogenitas melibatkan empat kelompok data yang berbeda. Kelompok data ini yaitu data siswa dengan motivasi tinggi dan rendah di kelas eksperimen dan control, diperoleh varians data hasil penelitian yang terdiri dari empat kelompok ini homogen.

Uji hipotesis dilakukan dengan menggunakan Uji ANAVA dua jalur digunakan untuk menganalisis data yang melibatkan dua nilai rata atau lebih. Data hasil uji ANAVA dua jalur untuk pengujian hipotesis dengan software SPSS dapat dilihat pada Tabel 2.

Tabel 2. Hasil uji Anava dua jalur

\begin{tabular}{|c|c|c|c|c|c|}
\hline Source & $\begin{array}{l}\text { Type III } \\
\text { Sum of } \\
\text { Squares }\end{array}$ & $d f$ & $\begin{array}{l}\text { Mean } \\
\text { Square }\end{array}$ & $F$ & Sig. \\
\hline $\begin{array}{l}\text { Correc } \\
\text { ted } \\
\text { Model }\end{array}$ & $\begin{array}{l}2976,87 \\
5^{\mathrm{a}}\end{array}$ & 3 & $\begin{array}{l}992,29 \\
2\end{array}$ & $\begin{array}{l}23, \\
084\end{array}$ & $\begin{array}{l}, 00 \\
0\end{array}$ \\
\hline $\begin{array}{l}\text { Interce } \\
p t\end{array}$ & $\begin{array}{l}195300 \\
625\end{array}$ & 1 & $\begin{array}{l}195300 \\
, 625\end{array}$ & $\begin{array}{l}454 \\
3,3 \\
42\end{array}$ & $\begin{array}{l}, 00 \\
0\end{array}$ \\
\hline $\begin{array}{l}\text { Model } \\
\text { pembe } \\
\text { lajara } \\
\mathrm{n}\end{array}$ & $\begin{array}{l}2175,62 \\
5\end{array}$ & 1 & $\begin{array}{l}2175,6 \\
25\end{array}$ & $\begin{array}{l}50 \\
612\end{array}$ & $\begin{array}{l}, 00 \\
0\end{array}$ \\
\hline $\begin{array}{l}\text { Motiv } \\
\text { asi } \\
\text { Model } \\
\text { pembe }\end{array}$ & 275,625 & 1 & $\begin{array}{l}275,62 \\
5\end{array}$ & $\begin{array}{l}6,4 \\
12\end{array}$ & $\begin{array}{l}, 01 \\
6\end{array}$ \\
\hline $\begin{array}{l}\text { lajara } \\
\mathrm{n} x \\
\text { Motiv } \\
\text { asi }\end{array}$ & 525,625 & 1 & $\begin{array}{l}525,62 \\
5\end{array}$ & $\begin{array}{l}12, \\
228\end{array}$ & $\begin{array}{l}, 00 \\
1\end{array}$ \\
\hline Error & $\begin{array}{l}1547,50 \\
0\end{array}$ & 36 & 42,986 & & \\
\hline Total & $\begin{array}{l}199825, \\
000\end{array}$ & 40 & & & \\
\hline $\begin{array}{l}\text { Correc } \\
\text { ted } \\
\text { Total }\end{array}$ & $\begin{array}{l}4524,37 \\
5\end{array}$ & 39 & & & \\
\hline
\end{tabular}

Hasil pengujian hipotesis dapat diketahui dengan melihat nilai signifikasi yang diperoleh. Apabila nilai signifikasi < 0,05 , Maka $\mathrm{H}_{1}$ : terdapat pengaruh model pembelajaran advance organizer terhadap hasil belajar siswa dapat diterima. Dari Tabel 2 dapat kita lihat nilai signifikasi untuk model pembelajaran 0,000 $<0,05$. Maka dapat disimpulkan bahwa terdapat pengaruh model pembelajaran advance organizer terhadap hasil belajar siswa.
Hal ini sejalan dengan dengan hasil uraian sebelumnya mengenai pengaruh yang diberikan model pembelajaran advance organizer terhadap terhadap hasil belajar siswa.

Sama dengan uji sebelumnya, pada uji hipotesis kedua ini $\mathrm{H}_{1}$ : Terdapat interaksi antara model pembelajaran dan motivasi terhadap hasil belajar akan diterima jika nilai signifikasi $<0,05$. Pada Tabel 2 dapat dilihat nilai signifikasi untuk interaksi model pembelajaran dan motivasi sebesar 0,001 $<0,05$. Sehingga dapat disimpulkan bahwa terdapat interaksi antara model pembelajaran dan motivasi terhadap hasil belajar.

Oleh karena terdapat interaksi, maka untuk mengetahui mana yang lebih tinggi diantara empat kelompok penelitian ini, perlu di lakukan uji lanjut. Dalam kasus ini peneliti menggunakan uji Tukey dengan bantuan software SPSS.

Data lengkap hasil uji Tukey dengan bantuan software SPSS dapat dilihat pada Tabel 3.

Tabel 3. Hasil uji Tukey

\begin{tabular}{|c|c|c|c|c|c|}
\hline & $\begin{array}{l}\text { (I) } \\
\text { Inte } \\
\text { raks } \\
\mathrm{i}\end{array}$ & $\begin{array}{l}(\mathrm{J}) \\
\text { Intera } \\
\text { ksi }\end{array}$ & $\begin{array}{l}\text { Mean } \\
\text { Differ } \\
\text { ence } \\
\text { (I-J) }\end{array}$ & $\begin{array}{l}\text { Std. } \\
\text { Error }\end{array}$ & Sig. \\
\hline \multirow{12}{*}{ Tukey } & \multirow{3}{*}{$\begin{array}{l}\text { A1B } \\
1\end{array}$} & A1B2 & $12,50^{*}$ & 2,932 & 001 \\
\hline & & A2B1 & $22,00^{*}$ & 2,932 & ,000 \\
\hline & & A2B2 & $20,00^{*}$ & 2,932 & ,000 \\
\hline & \multirow{3}{*}{$\begin{array}{l}\text { A1B } \\
2\end{array}$} & $\mathrm{~A} 1 \mathrm{~B} 1$ & $12,50^{*}$ & 2,932 & ,001 \\
\hline & & A2B1 & $9,50^{*}$ & 2,932 & ,013 \\
\hline & & $\mathrm{A} 2 \mathrm{~B} 2$ & 7,50 & 2,932 & ,068 \\
\hline & \multirow{3}{*}{$\begin{array}{l}\text { A2B } \\
1\end{array}$} & A1B1 & $22,00^{*}$ & 2,932 & ,000 \\
\hline & & A1B2 & $-9,50^{*}$ & 2,932 & ,013 \\
\hline & & A2B2 & $-2,00$ & 2,932 & ,903 \\
\hline & \multirow{3}{*}{$\begin{array}{l}\mathrm{A} 2 \mathrm{~B} \\
2\end{array}$} & $\mathrm{~A} 1 \mathrm{~B} 1$ & $-\overline{20}, 00^{*}$ & 2,932 & ,000 \\
\hline & & A1B2 & $-7,50$ & 2,932 & ,068 \\
\hline & & A2B1 & 2,00 & 2,932 & ,903 \\
\hline
\end{tabular}

Pada uji hipotesis ketiga ini $\mathrm{H}_{1}$ : Hasil belajar IPA pada pembelajaran advance organizer pada kelompok motivasi tinggi lebih tinggi dari hasil belajar siswa pada pembelajaran konvensional pada kelompok motivasi tinggi akan diterima jika nilai signifikasi $<0,05$. Pada Tabel 3 dapat dilihat nilai 
signifikasi untuk model pembelajaran advance organizer pada kelompok motivasi tinggi (A1B1) dengan model pembelajaran konvensional pada kelompok motivasi tinggi (A2B1) sebesar $0,000<0,05$. Sehingga dapat disimpulkan bahwa Hasil belajar IPA pada pembelajaran advance organizer pada kelompok motivasi tinggi lebih tinggi dari hasil belajar siswa pada pembelajaran konvensional pada kelompok motivasi tinggi.

Pada uji hipotesis keempat ini $\mathrm{H}_{1}$ Hasil belajar siswa dengan pembelajaran advance organizer pada kelompok motivasi rendah lebih rendah dari hasil belajar IPA dengan pembelajaran konvensional pada kelompok motivasi rendah akan diterima jika nilai signifikasi $<0,05$. Pada Tabel 3 dapat dilihat nilai signifikasi untuk model pembelajaran advance organizer pada kelompok motivasi tinggi (A1B2) dengan model pembelajaran konvensional pada kelompok motivasi rendah (A2B2) sebesar $0,068>0,05$.karna nilai signifikasi A1B2 dengan A2B2 lebih besar dari 0,05 maka hipotesis keempat yang berbunyi Hasil belajar IPA pada pembelajaran advance organizer pada kelompok motivasi rendah lebih rendah dari hasil belajar siswa pada pembelajaran konvensional pada kelompok motivasi rendah tidak dapat diterima.

\section{Pembahasan}

Perbedaan metode yang diberikan di kelas eksperimen dan kelas kontrol merupakan bagian dari desain penelitian yang telah dirancang sejak awal. Siswa kelas eksperimen belajar dengan menggunakan model advance organizer dan siswa kelas kontrol belajar dengan menggunakan metode konvensional. Dari hasil dekripsi data kita ketahui bahwa nilai rata-rata hasil belajar siswa kelas eksperimen sebesar 72,50. Sedangkan siswa kelas kontrol memiliki nilai hasil belajar sebesar 67,25. Berdasarkan perbedaan tersebut dapat dikatakan bahwa model pembelajaran advance organizer memberihkan pengaruh terhadap hasil belajar siswa. Dengan hasil, Pembelajaran dengan model advance organizer memiliki nilai hasil belajar yang lebih baik dari pembelajaran dengan model konvensional.

Seperti yang kita ketahui hasil uji hipotesis menunjukan bahwa terdapat interaksi anatara model pembelajaran dan motivasi terhadap hasil belajar siswa. Ini dibuktikan dengan nilai Signifikasi untuk interaksi model pembelajaran dan motivasi sebesar $0,001<0,05$. Kseimpulan hasil uji hipotesis ini menunjukan adanya interaksi antara model pembelajaran dengan motivasi menunjukan bahwa efektifitas dari model pembelajaran berkaitan erat dengan motivasi belajar siswa. Artinya, efektifitas model pembelajaran akan lebih baik apabila sesuai dengan tingkat motivasi yang dimiliki setiap individu. Sebaliknya,strategi pembelajaran akan gagal digunakan apabila tidak sesuai dengan tingkat motivasi belajar individu.

\section{KESIMPULAN}

Berdasarkan hasil analisa data dan pembahasan maka diperoleh beberapa kesimpulan, yaitu Terdapat pengaruh model pembelajaran advance organizer terhadap hasil belajar siswa pada pembelajaran IPA, Terdapat interaksi antara model pembelajaran dan motivasi terhadap hasil belajar, Hasil belajar IPA pada pembelajaraan Advance organizer pada kelompok motivasi tinggi lebih baik dari hasil belajar siswa pada pembelajaran konvensional pada kelompok motivasi tinggi, Hasil belajar IPA pada pembelajaran Advance organizer pada kelompok motivasi rendah lebih tinggi dari hasil belajar siswa pada pembelajaran konvensional pada kelompok motivasi rendah.

\section{DAFTAR PUSTAKA}

Hartono. (2014). Analisis Tingkat Motivasi Siswa dalam Pembelajaran IPA Model Advance Organizer Berbasis Proyek. Jurnal Pendidikan IPA Indonesia, 3(1), 43-50.

Riadi. (2016). Statistika Penelitian. Yogyakarta: Andi.

Slavin. (2010). Cooperative Learning Teori, Riset dan Praktik (Cetakan keVIII). Bandung: Nusa Media. 
Sudjana. (2005). Penilaian Hasil Proses Belajar Mengajar. Bandung: PT. Remaja Rodiskarya.

Sugiyarto, T. \& Ismawati, E. (2008). Ilmu Pengetahuan Alam. Jakarta: Pusat Perbukuan Departemen Pendidikan Nasional.

Sugiyono. (2013). Metode Penelitian Kuantitatif Kualitatif dan $R \& D$. Bandung: Alfabeta. 